\title{
THE LEGACIES OF THE NATIVES LAND ACT OF 1913
}

\author{
Ruth Hall \\ Institute for Poverty, Land and Agrarian Studies \\ University of the Western Cape
}

\begin{abstract}
Looking back at the century since the promulgation of the Natives Land Act, it could be argued that it shaped the trajectories of most South Africans' lives. It expelled black people from the land into crowded reserves and formed the cornerstone of the migrant labour system through which accumulation of wealth in white-owned mines, farms and factories followed. Far from unravelling this history of dispossession, the land reform process has merely dabbled at its edges while the inequalities it set in place have in some ways been further aggravated since 1994. Four legacies of the Act are identified: the material legacy of poverty and inequality in the divided countryside but also the displaced legacy of urban poverty and inequality; the social and spiritual legacy of division, invisibility and failed reconciliation; and a political legacy of legal pluralism and dualistic governance that denotes zones of tradition or custom, distinct from the rest of the country. In this context, the church needs to reflect, not only on its mixed involvement in dispossession and resistance to it in the past, but also on its role in dismantling the structures of poverty and inequality, social and spiritual division, invisibility and dualistic governance.
\end{abstract}

Key Words: Land Reform; Apartheid; Homelands; Restitution; Dispossession

\section{What was this Act?}

The Natives Land Act 27 of 1913: its promulgation is an infamous moment in South Africa's history, but the racist dispossession of black South Africans that is associated with it was not a moment. As Peter Delius and William Beinart (2013) point out, dispossession far preceded the Act. It was in many respects the culmination and confirmation of dispossession that had been underway in parts of the country, in the Cape Colony at least, for several centuries. And as Lungisile Ntsebeza and Thembela Kepe (2012) among others point out, its provisions were enforced unevenly and widely resisted. Yet it was a starting point of a new era of political, economic and spatial dualism, and its effects shaped South Africa throughout the $20^{\text {th }}$ century and in large part, as I will argue here, it is mainly intact today. The Act laid the foundation for segregation and apartheid through most of the rest of the century: the homeland policies of Hendrik Verwoerd, the imposition of state-approved and appointed Bantu Authorities, the system of influx control and the hated 'pass' laws, and in the towns and cities, the Group Areas Act. Forced removals continued right up to the 1970 s and 80s, as people in the so-called 'black spots' in the 'white' countryside clung to their land - at Doornkop in Mpumalanga, at Mgwali in the Eastern Cape, at Cremin in KwaZulu-Natal - but the insecurity created by the Act was experienced throughout.

The Act's provisions were fairly straightforward: 'scheduled areas' were created to serve as native reserves on about 7 percent of the country's land.

(2) From and after the commencement of this Act, no person other than a native shall purchase, hire or in any other manner whatever acquire any land in a scheduled native 
area or enter into any agreement or transaction for the purchase, hire or other acquisition, direct or indirect, of any such land or of any right thereto or interest therein or servitude thereover, except with the approval of the Governor-General (Union of South Africa 1913).

The wording of the Act expressed an illusion of parity between white and black.

a. a native shall not enter into any agreement or transaction for the purchase, hire, or other acquisition from a person other than a native, of any such land or of any right thereto, interest therein, or servitude thereover; and

b. a person other than a native shall not enter into any agreement or transaction for the purchase, hire, or other acquisition from a native of any such land or of any right thereto, interest therein, or servitude thereover.

The Act was designed to serve the claims of and reconcile conflicts among different mining and farming interests. It was prompted in part by the resentment among Highveld farmers of syndicated African purchases of land, settlement of African tenants on land owned by mining companies, and share and labour tenancies by African farmers and farm workers.

In terms of the 1913 Act, black tenants on white farms were to be given notice to leave. Violation of the terms of the Act could elicit a fine of 100 pounds or six months' imprisonment, among other penalties (Plaatje 1916:131). In the Orange River Colony, prior to the South African War and the British occupation in 1900, Presidential permission had been required for 'natives' to purchase land but, according to Plaatje (1916:130-131), this was readily granted. The eviction of black tenants in the Orange Free State, where absentee ownership had been common, prompted sizeable migrations of black livestock owners eastwards into Basotholand and northwards across the Vaal River. It also prompted the conversion of sharecropping arrangements into labour tenancy. Sol Plaatje gives a vivid account of the response by the Secretary for Native Affairs, Edward Dower, to a few thousand concerned African farmers at a public meeting in Thaba 'Nchu on 12 September 1913, and describes how the Secretary presented the available options for sharecropping farmers under the new Act:

The old practice of 'sowing on the halves' might continue so long as the lawfully executed contracts lasted; but at the expiration of those contracts the practice should cease, as Parliament had decided on its abolition. It amounted to a partnership between a white man and a black man. With a civilized Native the system might have been good, but a raw Native always got the worst of the partnership. He would advise them to make the best temporary arrangements within the four corners of the law. It might be by adopting one of three alternatives: (1) Become servants (in which case it would be legal for a master to give them pieces of land to plough and graze a number of stock); or (2) move into the reserve - (voices: "Where is the reserve?"); or (3) dispose of the stock for cash (Sensation) (Plaatje 1916:134-135)

Already recognising that the area set aside as reserves was inadequate to meet the needs of Africans and therefore the labour requirements of the mining industry (Lacey 1981), the Union government appointed a Native Lands Commission (the 'Beaumont Commission' after its chair, Sir William Beaumont) to identify additional land that could be incorporated into the reserves. The proposals of the Beaumont Commission, reporting in 1916, earmarked a further seven million hectares to extend the reserves which would constitute 12.7 percent of the country's surface (Union of South Africa 1916). White farmers criticised the report, arguing that its recommendations to expand the reserves would disturb white agriculture; its proposals were shelved and instead local committees advised on more 
limited 'released areas' (Platzky and Walker 1985:87). The land allocated to Africans under the Beaumont proposals would accommodate four million people, while 86 percent of the country would be set aside as white farming areas for a white population of 660000 (Plaatje 1916:409). As always, the realities were more complex: a large number of black people continued to live in the areas designated for white farming, but ignoring this fact has tended to endure even into the democratic era.

\section{Sol Plaatjie and the SANNC's Opposition to the Act}

Plaatje is one of the best contemporary sources on the Act, and reflects the opposition of the mission-educated African elite which had led the previous year to the formation of the South African Native National Congress. He was presented as a perfect English gentleman, Christian, impeccably dressed, and was a prolific writer. As Karen Haire and Daniel Matjila (2013) argue, he had 'the soul and sensibility of an African and a Motswana', and used rhetorical questioning and biblical allusions to depict the injustice of working life on farms and mines, asking for instance: 'Are not many of us toiling in the grain fields and fruit farms, with their wives and their children, for the white man's benefit?' He chose to focus on the most vulnerable and downtrodden members of society, and named and individualised the stories: the widow thrown off the land, the child who died in the winter, apparently from hunger and hardship, and whose parents, now landless, stole a piece of land, burying the child by stealth at night. He was part of the SANNC delegation to England in 1914, which petitioned the British parliament, pleading, without success, for it to invoke its imperial veto over South African legislation. Sandra Swart (2013) shows that Plaatje's plea to the British people was widely read, and was framed to legitimise the voice of the SANNC by emphasising its 'civility'. Plaatje's allegiance to class was ambiguous: he spoke about, rather than for, the workers, and expressed extra outrage at the humiliation of middle class blacks, for instance lamenting the lost dignity of the Minister's wife now rendered homeless. As Haire and Matjila put it, in his opposition to the 1913 Land Act, Sol Plaatje used the tools of the white man - learning and Christianity - to expose the hypocrisy of the white man. This is evident in the tone of the petition presented by the SANNC to King George V, which declares:

3) That petitioners are descendants of a race which, when their forebears were conquered by Your Majesty's might, and their land taken from them, their laws and customs mangled and their military and other institutions brought to nought, loyally and cheerfully submitted to Your Majesty's sway in the full belief that they would be allowed to possess their land as British subjects, and would be given the full benefits of British rule like all other British subjects (SANNC 1914).

And further:

(7) That petitioners say that when their forebears submitted themselves to the rule of the British Government, and paid homage to them, they fully accepted the Sovereignty of Great Britain and no other, but fully believed that their land would be reserved for them, and that they would have the full right of British subjects, more especially with regard to the possession of land and all the right incident thereto.

The objection to the Act itself is framed as a violation of the contract established between the 'natives' and colonial authorities prior to the Union, arguing:

(14) That petitioners most humbly say that the Native Lands Act No. 27 of 1913, passed by the Union Government, is an Act that has shown to the natives that the Union Government have overlooked the Queen's Government Proclamation, as quoted in 
paragraph 4 of this petition, and have started to pursue a policy towards the natives of entirely eliminating them from the interests of this country, and of ignoring their rights as British subjects, and are taking a course that must inevitably lead to disaster.

(15) That petitioners say this Native Lands Act has caused the greatest disappointment to, suspicions among, and the deepest opposition from, the native races.

(16) That petitioners say that they recognise that it is necessary to initiate without delay a policy dealing with the land question, and other questions affecting the Europeans and natives in this land, but most humbly and respectfully submit that the Union Government failed to do what was right with regard to the said Land Act.

(17) That the petitioners object to the said Land Act as being generally an act of class legislation, and one that would never have been dreamt of had only Europeans been in this land, and see in it the beginning of that policy towards the natives which will end in making them slaves.

(18) That petitioners beg permission to draw attention to the fact that it was the European who came to this land and settled in it alongside the native, and the native could not help it, and that they (the natives) most keenly feel and resent the spirit exhibited by the Europeans towards the native races by that Land Act.

(19) That the petitioners and the native races, while admitting the wisdom of initiating a policy to deal with the land question, and other cognate questions in this land without delay, most earnestly protest against the following with regard to the Native Lands Act of 1913 passed by the Union Government of South Africa, viz.:

1. It was conceived, framed and bought [sic] into the Union House of Parliament without any previous notice to the natives, and without consultation with the natives and without the taking of the natives into confidence as should have been done, seeing that the question at issue affects the natives more than any other subjects of Your Majesty.

2. It was dealt with in both Houses of Parliament in a most reprehensible hurry, and without consideration, and passed into law with such haste, as could never have been the case if the European subjects of Your Majesty were to be alone affected by the provisions thereof.

3. Its conception, its framing, and the manner of its being passed into law, is a precedent for future legislation in the Union Parliament with regard to questions affecting the natives, who are entirely unrepresented, though they pay a large sum in taxes, and are the majority of labourers and inhabitants of the Union of South Africa.

4. It was passed in such a crude and ambiguous shape that it is difficult to understand its true import, even after many explanations by those who think they can explain its meaning.

5. It has not yet been explained to most of the natives whom it affects as it should have been, and a vast number of natives have no explanation of it at all, but have commenced to feel its cruel effects.

6. It is an Act which instead of being based on the principles observed in the Cape Colony with regard to the natives and the land there, has been based on principles subversive of all that is right, just and likely to conserve the peace, prosperity and happiness of the various races of the Union of South Africa.

7. It is an Act whose provisions, if they are carried out as they stand, will mean the deprivation of the natives of their most sacred rights as British subjects, will turn 
them into slaves, and will create such a strained and bitter feeling between the white races and the native races as will always in the future mean opposition between the two races and continual conflicts.

8. It is an Act that ignores the natives and his [sic] feelings, and leads them to believe that the Union Government considers them nonentities in this the land of their birth, and they may only expect worse things in the future.

9. Its provisions are entirely opposed to the principles of British policy and justice, and are laden with dynamite tendencies which mean agitations, schemings, upheavals, and conflicts in this land we love so much, and the scandalising of the British name and prestige.

The British king and Parliament were unmoved and the SANNC withdrew its delegation at the onset of World War I, sending a further delegation and petition in 1918, emphasising their loyalty to the Crown through the war, and demanding the repeal of the Act in recognition of their allegiance.

Milestones in the implementation of the Act and the elaboration of segregation and apartheid included the Natives Trust and Land Act of 1936 which expanded the reserves to 13 percent, though even through the consolidation of this land into 'homelands' from the 1950s, the actual area never quite reached even 13 percent. At the same time, in the Cape Province and Orange Free State, 'coloured rural areas' were formalised, with an equivalent vision of self-governance, to legitimise the spread of dispossession. Homelands were expanded from physical reserves to notionally 'independent' TBVC states (Transkei, Bophuthatswana, Venda and Ciskei), wholly established by and accountable to the South African state, while stripping their inhabitants of citizenship. In 1991, the Natives Land Act (by then renamed the Black Land Act) was repealed, along with all other racially discriminatory land laws, and the Bantustan governments were dismantled. Yet their imprints are everywhere to be seen.

\section{What are the Legacies of the Act?}

Let us consider four legacies of the Act.

\section{- A Material Legacy of Rural Poverty and Inequality}

The most stark legacy of the Act is the combination of poverty and inequality in South Africa: while most South Africans now live in towns and cities, as of 2008, 57\% of those who are poor are in rural areas, and $77 \%$ of the rural population is poor (Leibrandt et al. 2010:37). The Act was a foundation for a dualistic agrarian structure. In the countryside, this takes the form of a still-stark division between, on the one hand, the deep poverty and underdevelopment in the ex-Bantustans which represent about $13 \%$ of South Africa and are home to 16 million people - a third of South Africa's population - and on the other, the development of successful capitalist farming in the white countryside, made possible not only by dispossession but also by politically-motivated production and export subsidies, price controls, regulated marketing through state control boards and trade protection. Though ostensibly zones of wealth, the white farmlands are of course also places of enormous inequality, with the children of farm workers - those producing the food - more likely to be suffering of malnutrition than any other children: by the turn of this century, one in three farm worker children were stunted from malnutrition (Department of Labour 2001:13). 
Still, the big picture is one of spatial inequality between the Bantustans and the rest of the country. Maps by Michael Noble and Gemma Wright (see Figure 1 below) show multiple indices of deprivation - a combination of 13 variables covering income, employment, education, living conditions and health. Looking at these, what is at once shocking and unsurprising is the fact that regions of most extreme deprivation across these variables correlate almost perfectly with the former boundaries of the Bantustans. So while the boundaries were dismantled with the repeal of the Land Act in 1991, the structure has not. Economically, the Bantustans are intact.

Figure 1: Multiple indices of deprivation: the legacies of the Bantustan policy.

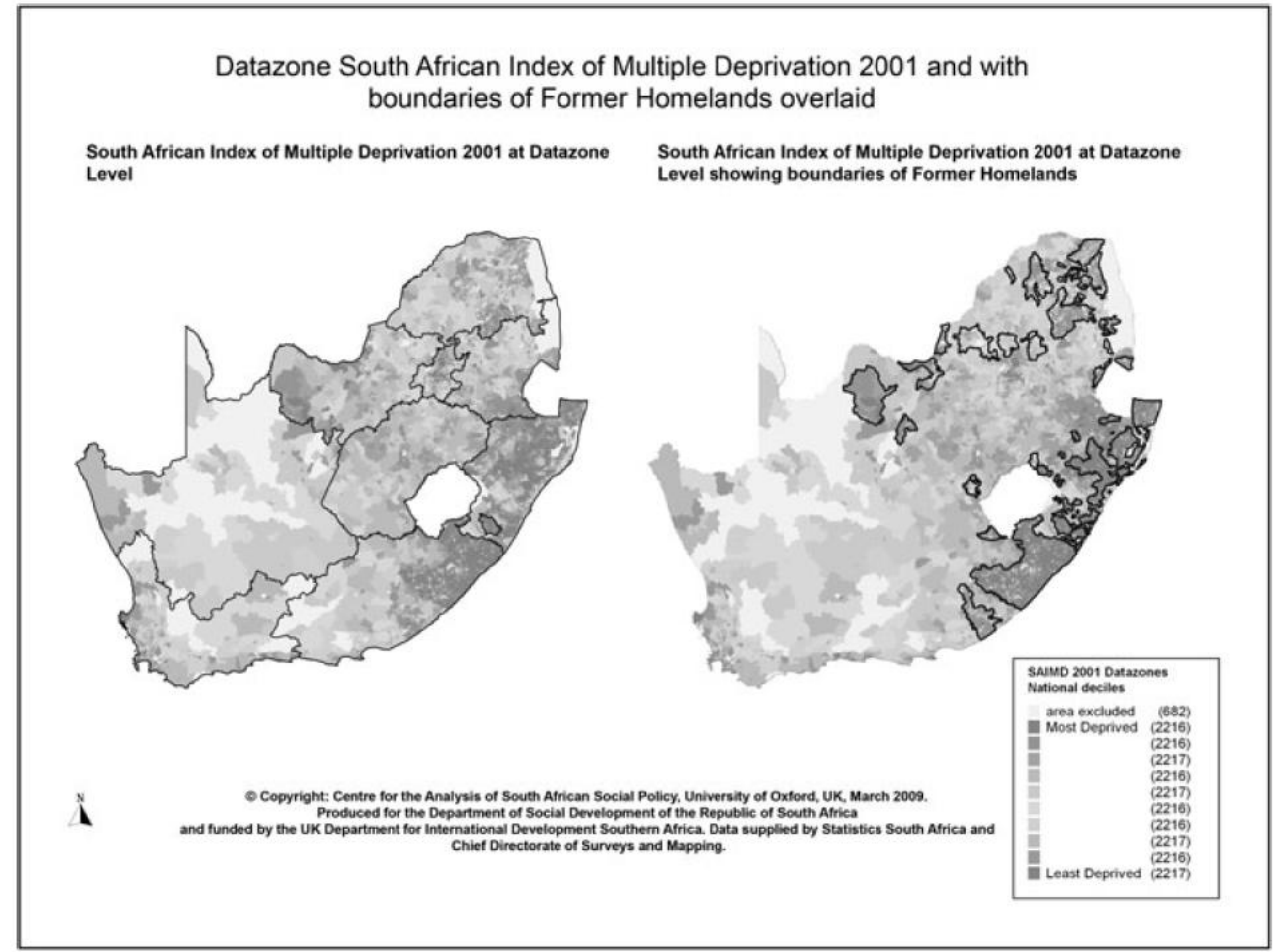

*Source: $\quad$ Noble, Michael \& Gemma Wright. 2013. Using Indicators of Multiple Deprivation to Demonstrate the Spatial Legacy of Apartheid in South Africa. Social Indicators Research. Vol 112(1):193.

Yet in some respects it is not. The migrant labour system which underpinned the Bantustans - and which enabled the accumulation of wealth in the mines, factories and other sectors - has been hit by de-industrialisation and the contraction of the mining sector in particular, leading to a loss of remittances in the 'communal areas' as they are now called somewhat euphemistically. The one factor mitigating the devastating loss of these cash incomes has been the provision of social grants, now the cornerstone of most rural people's livelihoods. Harold Wolpe (1972) argued that the system established by the Land Act was one of 'labour reserves', in that these were areas where social reproduction happened, largely through women's labour and women's farming, while male migrants could be paid below living wages. Martin Legassick (2013) quotes the government's 1944 Mine Natives 
Wages Commission which explained in the 'bosses' language' that the mining industry could not have developed:

... but for the fact that the cheap unskilled labour necessary has been available through the migrant native being prepared to sell his labour at a price rendered possible by his possession of a supplementary means of subsistence from his holding in a Reserve.

What progress has been made towards redressing this material legacy of poverty and inequality? Pitifully little. Land reform is often seen as the main means of doing so, but this has not happened. Redistributing land, and making sure that people have secure rights to their land, is an important starting point. But the country has not progressed very far even in laying this foundation. About 6.5 percent of commercial farmland is reported as being transferred to black South Africans in the past 19 years - since 1994 (SAnews.gov.za. 2013). The process has been, on the advice of the World Bank and the insistence of the ANC, based on voluntary market transactions and the protection of private property. The hard-won provisions in the Constitution for expropriation of property, for land reform purposes and with compensation, have been barely used, despite plenty of political rhetoric to the contrary. To the extent that it is happening, the redistribution of land has been recast from a project of resettling large numbers of the rural poor on land of their own, to reconstitute communities (with a secure place to stay), and to embark on more sustainable and diversified livelihoods; to one of settling a modest number of promising individuals on farms and enabling the deracialisation of commercial farming. Land reform, such as other kinds of transformation, raises fraught political questions about how to address inequalities of both race and class. Yet the contraction of the redistribution programme suggests a story largely of elite capture: compared to 144000 people benefitting in the first 6 years of the programme, about 10000 benefitted in the first three years of the Zuma administration, during which time budgets were substantially increased. This translates to about 800 households per year, benefitting from a budget of about R1.5 billion (DRDLR 2012:22, National Treasury 2013). So, while the political temperature around 'the land question' is on the rise - a discourse which suggests that any transfer from white to black, or from white to the state, is unambiguously a step forward - this is liable to obscure the real politics and the ever-present potential for elite capture by politically-connected elites.

\section{- A Displaced Legacy of Urban Poverty and Inequality}

Land reform is not the only, or perhaps even the most central way of reversing the legacy of the Act. Instead of seeing the Act and its legacy as 'rural' phenomena, they can and should be understood as both rural and urban, with the inequalities, both economic and spatial, that mark our apartheid cities also being quite intact. A child growing up in poverty in Khayelitsha is a victim of the 1913 Land Act as much as a child growing up in poverty in Lusikisiki, or a child growing up in poverty on a white-owned farm in the KwaZulu-Natal Midlands. The wealth of the cities, of the mining, industrial and technological hubs, are as much the product of the existence of labour reserves and cheap migrant labour as the commercial farms. This is what complicates the 'land question'.

In thinking about the idea of 'reversing' the legacies of the Act, we should remain aware that this is not a simple matter either of restoring the land, or some kind of turning back the clock. As Cherryl Walker (2008) argues, there is a 'master narrative of loss and restoration' in public discussions on dispossession and land reform which presents dispossession as an unproblematic, linear and evenly-experienced process, characterised by 
and presupposing that restoration similarly can somehow turn back the clock. As she observes, the problem

... is not that the constituent elements of this political fable are in themselves incorrect but that the narrative simplifies, excludes and reduces too much. It runs together very different periods and relationships to land and collapses very differently constituted groups into the single category of 'the dispossessed'. It glosses over class and gender and ethnicity and generation, as well as locality. In working at the level of the general it plays from the contrariness of the specific and fails to accommodate important deviations from its script... As the basis for state policy it is unable to come to terms with the profound changes that have taken place not only among the dispossessed but also on the land in society more broadly in the years since the devastation of the population removals from which it claims its authority (Walker 200842-43).

When thinking about the legacies of the Land Act, many of the people themselves, their livelihoods, and a vast proportion of the wealth that their dispossession enabled, have urbanised. Now, the capital accumulated through the exploitation of cheap migrant labour, on farms, factories and mines, is sitting in the stock exchange. Yes, the wealth is still evident in the rich countryside, but it is a mistake to consider the land itself, the artefact of historical processes of dispossession and accumulation, as holding in totality the key to the reversal.

Not only have people moved on - dispossession did not end with apartheid. It continues under democracy, and those being dispossessed again are almost without exception poor and black. Now we have laws to regulate how this happens, and the Constitution requires a court order before anyone is evicted, and various laws specify additional requirements for different people and circumstances. Yet even so, people continue to be evicted from their homes with no alternatives being available to them - in other words, they are left destitute, landless and homeless. From available information the largest single category of the dispossessed of the post-apartheid era are farm workers and farm dwellers - bearing in mind that most people who live on farms are not employed there, but are either families of workers, or in some parts of the country (especially Limpopo, Mpumalanga and KwaZuluNatal) they are tenants who have lived there for generations - another example of how the Land Act was not fully enforced, but allowed owners to extract rents in the forms of sharecropping, labour tenancy and cash rents. The only national survey on farm evictions found that nearly 2 million black people moved off farms in the first decade of democracy: 1994 to 2003. And of them, 940000 were forcibly evicted (only 1 percent through a legal process as required by the Constitution). So, long after the Act's repeal, dispossession continues. Rather than always talking about 'apartheid-era dispossession', we need now to add to our lexicon 'post-apartheid dispossession'. If you are on the receiving end, it may not look so different.

What is now interesting is that labour unions - and the urban working class - have become more vocal on the land issue. This may well be a function of the attention to the centenary of the Act, but my sense is that it reflects a reconsideration of where the 'Polokwane' project of economic transformation has gone awry and, following the Marikana massacre and the farm worker strikes of 2012, growing demands for more substantive change across many sectors of the economy. During 2013 the National Union of Metalworkers of South Africa and the Food and Allied Workers' Union launched a joint 'Campaign for Agrarian Transformation and Land Redistribution', calling on government to use the existing expropriation provisions of the Constitution, and to amend the property clause to remove the power of the courts to adjudicate compensation, to finalise a new 
White Paper, to sort out communal tenure, and to stop evictions of farm workers and dwellers. In a new departure, their demands are not only that redistribution be speeded and scaled up, but also that ownership and control over the whole food chain be transformed, arguing that it is not only commercial farmers but increasingly big agribusiness, food manufacturing, input industries and, at the retail end of the value chain, the supermarkets, that are now, profiteering from the poor on the back of dispossession. This suggests a powerful reframing of the 'land' question, and its expansion to a question of the right to food, a reframing that potentially unites diverse and disparate social forces, across the rural and urban divide.

So far, the material legacy of the Act, the poverty, inequality and suffering that it provoked, is a society-wide grievance, which is widely recognised. It is usually this material legacy that we focus on when talking of 'the land question'.

\section{- A Social and Spiritual Legacy of Division, Alienation and Invisibility}

But we are not merely economic beings - as theologians are likely to agree. The Land Act has cast a pall across society, creating rifts and divides, and leaving a social and spiritual legacy. Where communities have been divided, where citizenship was denied and identities imposed - what kinds of redress are needed?

In studies on the land claims process in which people can claim back land that they lost as a result of the Land Act and subsequent laws and practices, as long as it was after 19 June 1913, many people were dissatisfied with the form that restitution took. In dealing with restitution claims, memorialisation is an element that has been missed. In the small town of Riebeeck-Kasteel, the anthropologist Anna Bohlin (2004) interviewed claimants who, having received and spent the cash compensation provided as restitution, pointed out that in the town where they had lived, there was no sign that they were ever there. The town, like so many, is still divided into 'bo-dorp' and, four kilometres away, an 'onderdorp', the 'coloured township' of Esterhof, established in the 1960s when the coloured residents were forcibly removed from the town when it was declared a white area under the Group Areas Act. Restitution did nothing to re-insert the people into the town centre, or even the memory of their prior lives there. "It is as if someone in town took up a stone and threw it as far away as they could, saying 'that's where you must live" (Bohlin 2004:677). There, the 'sacrality' of land was intensified after its loss; rather than a single moment, loss of land

... is a dynamic process that continues to affect them into the future... People still speak about their loss. Most claimants walk past their former area of living on a daily, or at least weekly, basis. The prosperity of the white homes, the lush vineyards that they see there, are a constant reminder of the high price they paid and the inadequacy of the compensation provided. Most significantly, claimants mourn the loss of their church, a stone building that was also used as a school. After its demolition, only photographs and the church bell remained.

Claimants have discussed lodging a further claim, for the restoration of the church and school, as representing the presence, in the past and into the future, of this community. The local museum depicts the history of white settlers, but contains none of this history. As one claimant commented:

... white people have their church, where they can see their history, but we don't have ours'. She lamented that white residents showed little awareness of, or interest in, restitution and said that she would like a formal apology from the white community for 
the destruction of the church. For her, the absence of any formal engagement with those regarded as responsible for, or as having benefitted from, land dispossession is a serious shortcoming of the restitution programme (Bohlin 2004:681-2).

Similarly, Uma Dhupelia-Mesthrie, writing about claimants who were forcibly removed from the Black River area in what is now Rondebosch, observes that their grievances also extend beyond injustice, the loss of a physical asset, past suffering and continuing poverty, to a concern with invisibility. She notes that 'traces of the Black River community have been erased from Cape Town's memory and geography. All we have is a suburb of Rondebosch, a Black River parkway, and a canalized river that fails to evoke its past' (Dhuphelia-Mesthrie 2010:83).

My point is that the restitution process focused only on the material question of restoring land or granting compensation in the form of cash. Restitution was separated from human relations. While the Truth and Reconciliation Commission focused on 'gross human rights violations', there was no equivalent process on land dispossession. Indeed, we acknowledge no beneficiaries. One of the goals of restitution was to create 'reconciled' communities, yet the process itself involves little evidence of attempts to reconcile. There is a disconnection between restitution through a Commission on the Restitution of Land Rights (CRLR) and reparation through a Truth and Reconciliation Commission (TRC) despite a 'common vocabulary of reconciliation, healing and justice' (Dhupelia-Mesthrie 2010: 85). What about those who benefitted from dispossession - white (and corporate) owners who obtained land cheaply from the previous government and may have developed it with public subsidies and cheap labour? Do they have any responsibility in the restitution process? No: in the restitution process, there are no beneficiaries. In the TRC, there were perpetrators, but in the restitution process, there are only victims - the state and victims.

In this context, we need to ask why, on the one hand, our society recognises that grievous harm was done to most of our population, and that as a country we need to invest in a lengthy and costly process to restore justice - yet we try to do so privately, in negotiations between the state and claimants, only bothering those whose property is directly implicated when it is to be bought from them - rather than surfacing the murky and complex questions of who benefited, how and what this means for us all today.

\section{- A Political and Legal Legacy of Dualistic Governance}

I suggest a fourth dimension, a political legacy of the Land Act which centres on governance and authority, and it requires looking squarely at the points of friction between constitutional rights, tradition and custom. The political (and legal) legacy that is seldom discussed as one of the legacies of the 1913 Land Act is the still-contentious and unresolved question of civil versus traditional forms of governance. While the Constitution says that "The Bill of Rights does not deny the existence of any other rights or freedoms that are recognised or conferred by common law, customary law or legislation, to the extent that they are consistent with the Bill", in practice legal and policy processes over the past two decades have moved in the direction of providing tribal authorities with expanded powers, often in tension with constitutional provisions. The Traditional Leadership Framework Governance Act 41 of 2003 recognised traditional leaders and provided for the establishment of 'traditional councils' made up of these state-appointed leaders, together with a minority number of elected members. The Communal Land Rights Act 11 of 2004 proposed to transfer ownership of land in the communal areas to 'traditional communities', to be administered by these chief-dominated councils. A legal challenge by four 
communities who objected to this went all the way to the Constitutional Court, where they argued that it denied people in these areas the rights to democratic governance, to gender equality and that it would not secure their rights to land - as required by a specific clause in the Constitution. Meanwhile, the Bantu Authorities Act of 1951 (now the Black Authorities Act) remains in force. Its imposition, together with the pass laws, provoked rural protests in many areas, including the 'Pondoland Revolt'. Now, state-appointed chiefs - some with strong legitimacy and support from their communities and others unpopular and abusing their positions of authority over their 'subjects' - are salaried civil servants, able to determine what is 'custom'. The Traditional Courts Bill (TCB) controversially proposes that traditional leaders acquire powers not only to make the law and implement the law, but also to adjudicate it - thereby fusing the functions of the legislative, executive and judiciary in institutions without formal mechanisms of accountability to the people they preside over. The TCB even proposes that traditional courts should have the power to remove people's land rights as a form of punishment - a final flouting of the idea that a new South Africa would provide people with secure land rights. Of course this only applies to people living in areas where, according to the state, they should live by 'custom', a form of custom which is defined by the Bantu Authorities Act of 1951 and the Native Administration Act of 1927, both of which are still on the law books and in force, and felt in the lives of people. As the prominent activist Nomboniso Gasa argued at the Land Divided conference,

In the name of culture and custom, these laws mean in Cofimvaba I cannot own the land, but a tribal authority can. I fall under no tribal leadership of any kind, but because of a geographical location, I am subjected to an identity that I cannot escape (Gasa 2013 personal communication).

This suggests that, not only are the economic structures of the Bantustans intact, but actually the legal frameworks on which they were built remain in place, threatening to convert citizens back into subjects, within the borders of the reserves.

So far, I have outlined the legacies as I see them - the material legacy of poverty and inequality in the divided countryside but also the displaced legacy of urban poverty and inequality; the social and spiritual legacy of division, invisibility and failed reconciliation; and a political legacy of legal pluralism and dualistic governance that denotes zones of tradition or custom, distinct from the rest of the country.

\section{What does this mean for the Church?}

Having suggested three legacies, I suggest three questions for discussion and debate within the church and among theologians.

First is the question of the church's implication in land dispossession. This entails interrogating its direct involvement, as well as the ways in which the church tolerated the cover of Christianity as a justificatory framework for segregation and apartheid, and for the geographic separation of people.

Second is the need to reflect on the role played by the church, by clergy individually and collectively, and by the church as community in resisting dispossession. The church held land on behalf of and in trust for people, as a cover against an abusive state, and the mission stations of the Western Cape continue to do so, as well as in the former Act 9 or 'coloured rural areas'. The church used its position in society in South Africa and, through solidarity links, around the world, to challenge apartheid as a system and the forced removals that were central to its project. And liberation theology provided a framing and a springboard for engagement with demands for political and economic liberation. 
Third is a suggestion that, building on this critical appreciation of the complex roles of the church in the past, there is a need to question the role of the church, of religions in general - in the contemporary period. On this, I must say, in the public discourses around land specifically, I can only state that I have observed a remarkable silence. On other issues of course various leaders have rolled up their sleeves and become deeply involved in supporting campaigns for improvement in people's lives - the role of Bishop Thabo Makgoba comes to mind. But I think the question still stands: in a land divided, how can the church, church leaders, theologians, and the church as community, address the legacies of the 1913 Land Act? What spaces exist or must be created to challenge the continued realities of poverty and inequality? What is your role in confronting the tensions between traditional authority and constitutional rights? What is your role in bringing people back together - physically, legally, economically, socially and spiritually?

\section{BIBLIOGRAPHY}

Bohlin, Anna 2004. 'A Price on the Past: Cash as Compensation in South African Land Restitution.' Canadian Journal of African Studies. Vol 38, No 3:672-687.

Delius, Peter and William Beinart 2013. 'The historical context and legacy of the Natives Land Act of 1913.' Paper presented at the Land Divided conference, University of Cape Town. 24-27 March 2013.

Dhupelia-Mesthrie 2010. 'Urban Restitution Narratives: Black River, Cape Town' in Cherryl Walker, Anna Bohlin, Ruth Hall and Thembela Kepe (eds.) Land, Memory, Reconstruction and Justice: Perspectives on Land Claims in South Africa. Athens OH: Ohio University Press and Scottsville: University of KwaZulu-Natal Press. 83-99.

DOL (Department of Labour) 2001. Determination of Employment Conditions in South Africa Agriculture. Government Gazette, Vol 435, No 22648, 13 September 2001.

DRDLR (Department of Rural Development and Land Reform) 2012. Mid-term Review of the Department of Rural Development and Land Reform. Pretoria: DRDLR.

Gasa, Nomboniso 2013. Comments in closing plenary session. Land Divided conference, University of Cape Town, 24-27 March 2013.

Haire, Karen and Daniel Matjila 2013. 'Plaatje's elevation of the down-trodden black South African mine, farm \& domestic worker in Native Life in South Africa \& The Mote $\&$ The Beam.' Paper presented at the Land Divided conference, University of Cape Town, 24-27 March 2013.

Kepe, Thembela and Lungisile Ntsebeza 2012. Rural Resistance in South Africa: The Mpondo Revolts after Fifty Years. Claremont: University of Cape Town Press.

Lacey, Marian 1981. Working for Boroko: The Origins of a Coercive Labour System in South Africa. Johannesburg: Ravan Press.

Legassick 2013. 'The Natives Land Act in its wider context'. Presentation to National Union of Metalworkers of South Africa short course. Institute for Poverty, Land and Agrarian Studies, University of the Western Cape, 4-8 February 2013.

Leibbrandt, Murray, Ingrid Woolard, Arden Finn and Jonathan Argent 2010. 'Trends in South African Income Distribution and Poverty since the Fall of Apartheid.' OECD 
Social, Employment and Migration Working Paper No. 101. Paris: Organisation for Economic Co-operation and Development.

National Treasury 2013. 'Vote 33: Rural Development and Land Reform' in Estimates of National Expenditure. Pretoria: National Treasury.

Noble, M and Wright, G 2013. 'Using Indicators of Multiple Deprivation to Demonstrate the Spatial Legacy of Apartheid in South Africa.' Social Indicators Research, Vol 101:187-201.

Plaatje, Sol (Solomon) T 1916. Native Life in South Africa: Before and Since the European War and the Boer Rebellion. Johannesburg: Ravan Press.

Platzky, Laureen and Cherryl Walker 1985. The Surplus People: Forced Removals in South Africa. Johannesburg: Ravan Press.

SAnews.gov.za 2013. 'South Africa to speed up land reform.' 25 February 2013. www.southafrica.info/about/social/land-250213b.htm (accessed 24 May 2013).

Swart, Sandra 2013. It is as bad to be a black man's animal as it is to be a black man - the politics of animals in the 1913 Land Act. Paper presented at the Land Divided conference, University of Cape Town, 24-27 March 2013.

Union of South Africa 1913. Natives Land Act, No 27 of 1913. Pretoria: Government Printers.

Walker, Cherryl 2008. Landmarked: Land Claims and Land Restitution in South Africa. Cape Town: Jacana.

Wolpe, Harold 1972. 'Capitalism and Cheap Labour Power in South Africa: From Segregation to Apartheid.' Economy and Society, vol. 1, no. 4:425-456. 